\title{
Purification and comparison of heat shock protein 90 (Hsp90) in Candida albicans isolates from Malaysian and Iranian patients and infected mice
}

\begin{abstract}
Objective: The purposes of this study were to purify and compare the concentration ratios of heat shock protein 90 (Hsp90) in clinical isolates of Candida albicans (C. albicans) obtained from Malaysian and Iranian patients and infected mice. Materials and methods: Hsp90 was extracted using glass beads and ultracentrifugation from yeast cells and purified by ion exchange chromatography (DEAE-cellulose) and followed by affinity chromatography (hydroxyapatite). Purity of Hsp90 was controlled by SDS-PAGE and its identification was realized by immunoblotting test. Results: The graphs of ion exchange and affinity chromatography showed one peak in all C. albicans isolates obtained from both Malaysian and Iranian samples, infected mice and under high-thermal $\left(42{ }^{\circ} \mathrm{C}\right)$ and low-thermal $\left(25^{\circ} \mathrm{C}\right)$ shock. In immunoblotting, the location of Hsp90 fragments was obtained around 47, 75 and $82 \mathrm{kDa}$. The least average concentration ratios of $\mathrm{Hsp} 90$ were 0.350 and $0.240 \mathrm{mg} / \mathrm{g}$ for Malaysian and Iranian isolates at $25^{\circ} \mathrm{C}$, respectively, while the highest average concentration ratios of Hsp90 were 3.05 and $2.600 \mathrm{mg} / \mathrm{g}$ for Malaysian and Iranian isolates at $42{ }^{\circ} \mathrm{C}$, respectively. There were differences in the ratio amount of Hsp90 between Malaysian isolates $(1.01 \pm 0.07 \mathrm{mg} / \mathrm{g})$ and mice kidneys $(1.23 \pm 0.28 \mathrm{mg} / \mathrm{g})$ as well as between Iranian isolates $(0.70 \pm 0.19 \mathrm{mg} / \mathrm{g})$ and mice kidneys $(1.00 \pm 0.28 \mathrm{mg} / \mathrm{g})(\mathrm{P}<0.05)$. Conclusion: The results showed differences in all situations tested including Iranian and Malaysian isolates, samples treated with temperatures $\left(25{ }^{\circ} \mathrm{C}\right.$ or $\left.42{ }^{\circ} \mathrm{C}\right)$ and before and after infecting the mice $\left(37{ }^{\circ} \mathrm{C}\right)$, indicating higher virulent nature of this yeast species in high temperature in human and animal models.
\end{abstract}

Keyword: Candidiasis; Candida albicans; Heat shock protein; Malaysian and Iranian populations; Chromatography 